\title{
Malignant Lymphoma Localized in the Abdomen: Detection of Ig Gene Rearrangement from the Specimen Obtained by Percutaneous Lymph Node Biopsy
}

\author{
Takaaki Chou, Takao Irri, Kazuyuki Kurasige, Satoshi Ito, Masaya WaKabayashi, \\ Naoki HaYAshi* and Masaaki AraKawA
}

\begin{abstract}
A 32-year-old man was admitted to our hospital because of lumbago and an abdominal mass revealed by abdominal ultrasonography. Abdominal CT scan and MRI revealed multiple para-aortic lymph node swelling involving several arteries and veins. As there was no superficial lymph node swelling, percutaneous lymph node biopsy was performed under ultrasonographic guide. Although non-Hodgkin's lymphoma, diffuse, small cell type was suspected by light microscopic study, the monoclonality of the lymphocytes in the obtained specimen was not clear by the immunohistochemical study. Southern blot hybridization analysis of the biopsy specimen revealed the rearrangement of $\operatorname{IgH}$ and $\operatorname{IgL}(\lambda)$ chain gene, indicating the existence of monoclonal proliferation of lymphoma cells. The DNA analysis appears useful for the differential diagnosis of lympho-proliferative diseases.
\end{abstract}

(Internal Medicine 31: 1281-1285, 1992)

Key words: non-Hodgkin's lymphoma, ultrasonic echogram guide biopsy, southern blot hybridization method, monoclonal Ig gene rearrangement

\section{Introduction}

Recent progress in molecular biology and technology have enabled us to examine and understand lymphoid cell differentiation, maturation and the mechanism of immunological recognition (1). Using DNA analysis, it has been demonstrated that B lymphocytes go through immunoglobulin gene rearrangement and $\mathrm{T}$ lymphocytes go through $\mathrm{T}$ cell receptor gene rearrangement during their maturation and differentiation $(1-4)$. Those findings and the use of the Southern blot hybridization technique provide definitive information about the origin of the lymphoid cells analyzed. In the present paper, we report a case of non-Hodgkin's lymphoma localized in the para-aortic lymph node area, in which percutaneous lymph node biopsy and the Southern blot hybridization analysis of the obtained specimen was helpful in making the diagnosis.

\section{Case Report}

for the scrutiny of an abdominal mass. Two months before admission, he had dull pain in his back and consulted a general physician. As he had a history of renal stone since 15 years old, urinalysis revealed microscopic hematuria and ultrasound echography of the abdomen showed a large stone in the rt-carix. In addition to these findings, a large mass ( $8 \mathrm{~cm}$ in diameter) was found at the para-aortic area in the abdomen. He was introduced to our out-patient clinic for further examination and was admitted to our hospital.

\section{Physical findings on admission}

His body temperature was $36.5^{\circ} \mathrm{C}$, pulse rate $48 / \mathrm{min}$ with arrhythmia, and blood pressure $104 / 64 \mathrm{mmHg}$. The heart and the lung were not remarkable. In the abdomen, a solid tumor mass $(8 \mathrm{~cm}$ in diameter) was palpable near the navel. The tumor was elastic-hard, unmovable, but there was no tenderness or radiation pain. Other than the finding of this tumor, there was no superficial lymph node swelling.

\section{A 32-year-old man was admitted to our hospital}

From the Department of Medicine (II), Niigata University Medical School and *the Division of Internal Medicine, Niigata Cancer Center Hospital, Niigata

Received for publication May 18 1992; Accepted for publication September 2, 1992

Reprint requests should be addressed to Dr. Takaaki Chou, the Department of Medicine (II), Niigata University Medical School, Asahimachidori1, Niigata 951, Japan 


\section{Chou et al}

Table 1. Laboratory Findings on Admission

\begin{tabular}{|c|c|c|c|c|c|}
\hline $\mathrm{RBC}$ & $456 \times 10^{4} / \mu \mathrm{l}$ & $\mathrm{T}-\mathrm{P}$ & $6.9 \mathrm{~g} / \mathrm{dl}$ & GOT & $14 \mathrm{IU} / 1$ \\
\hline $\mathrm{Hb}$ & $15.4 \mathrm{~g} / \mathrm{dl}$ & Alb. & $73.0 \%$ & GPT & $17 \mathrm{IU} / 1$ \\
\hline Ht & $43.7 \%$ & $\alpha 1$ & 2.4 & $\mathrm{LDH}$ & $365 \mathrm{IU} / 1$ \\
\hline Plt & $14.8 \times 10^{4} / \mu \mathrm{l}$ & $\alpha 2$ & 4.7 & ALP & $151 \mathrm{IU} / 1$ \\
\hline WBC & $4,200 / \mu 1$ & $\beta$ & 9.5 & T-B & $1.3 \mathrm{mg} / \mathrm{dl}$ \\
\hline $\mathrm{St}$ & $4.5 \%$ & $\gamma$ & 10.4 & $\mathrm{ChE}$ & $5365 \mathrm{IU} / 1$ \\
\hline $\operatorname{Scg}$ & 64.0 & & & & \\
\hline Eo & 0.5 & BUN & $12 \mathrm{mg} / \mathrm{dl}$ & & \\
\hline Bas & 0.5 & Cre & $0.9 \mathrm{mg} / \mathrm{dl}$ & ESR & $3 \mathrm{~mm} / \mathrm{hr}$ \\
\hline Lym & 23.0 & $\mathrm{Na}$ & $144 \mathrm{mEq} / 1$ & CRP & $<0.25$ \\
\hline \multirow[t]{2}{*}{ Mono } & 7.5 & $\mathrm{~K}$ & $4.1 \mathrm{mEq} / 1$ & & \\
\hline & & $\mathrm{Cl}$ & $108 \mathrm{mEq} / 1$ & IgG & $1030 \mathrm{mg} / \mathrm{dl}$ \\
\hline U-P & $(-)$ & $\mathrm{Ca}$ & $9.4 \mathrm{mg} / \mathrm{dl}$ & $\operatorname{IgA}$ & $106 \mathrm{mg} / \mathrm{dl}$ \\
\hline $\mathrm{U}-\mathrm{S}$ & $(-)$ & IP & $2.8 \mathrm{mg} / \mathrm{dl}$ & $\mathrm{IgM}$ & $60 \mathrm{mg} / \mathrm{dl}$ \\
\hline \multicolumn{6}{|l|}{ U-sedi } \\
\hline RBC & $21-30 / \mathrm{hpf}$ & Ccr & $122 \mathrm{ml} / \mathrm{min}$ & \multicolumn{2}{|c|}{ anti-DNA Ab $(-)$} \\
\hline WBC & $3-5 / \mathrm{hpf}$ & & & \multicolumn{2}{|c|}{ SS-A Ab (-) } \\
\hline Epi & $3-5 / h p f$ & & & \multicolumn{2}{|c|}{ SS-B Ab (-) } \\
\hline
\end{tabular}

\section{Laboratory findings on admission}

As shown in Table 1, microscopic hematuria due to a renal stone was observed in urinalysis. Except for this, there were no remarkable abnormal findings in peripheral blood counts, serum protein, electrolytes, renal function, and liver function. There was no elevation of serum tumor-markers, such as CEA, CA19-9, and AFP. Serum amylase level was within the normal limits. The serum immunoglobulin level was normal, and autoantibodies were negative. Stool occult blood reaction was negative.

\section{Radiographic examination}

A chest X-ray film, upper G-I tract examination and Barium enema examination showed no abnormal findings. On ${ }^{67} \mathrm{Ga}$ scintigraphy (Fig. 1), abnormal isotope accumulation was observed in the abdomen, probably coinciding with the abdominal mass. Other than this finding, there was no other abnormal accumulation. On abdominal CT scan (Fig. 2), a large tumor mass, at the right renal pelvis level, approximately $7 \mathrm{~cm}$ in diameter was observed. The tumor oppressed the inferior vena cava to the front side. The right renal artery penetrated the tumor, indicating the tumor may be soft and not invasive to the vessels. No other para-aortic or mesenteric lymph node swelling was observed. In an magnetic resonance imaging (MRI) study (Fig. 3), a tumor mass $(8 \times 7 \times 15 \mathrm{~cm})$ from Th12 to L4 level, was observed.

\section{Histological examination}

From rentogenographic findings, malignant lymphoma, localized in the abdominal lymph nodes was suspected and tumor biopsy planned for difinitive histological diagnosis. At first, laparotomy was considered, but after close examination of roentogenic findings and discussion with surgeons, it was realized that an open laparotomy

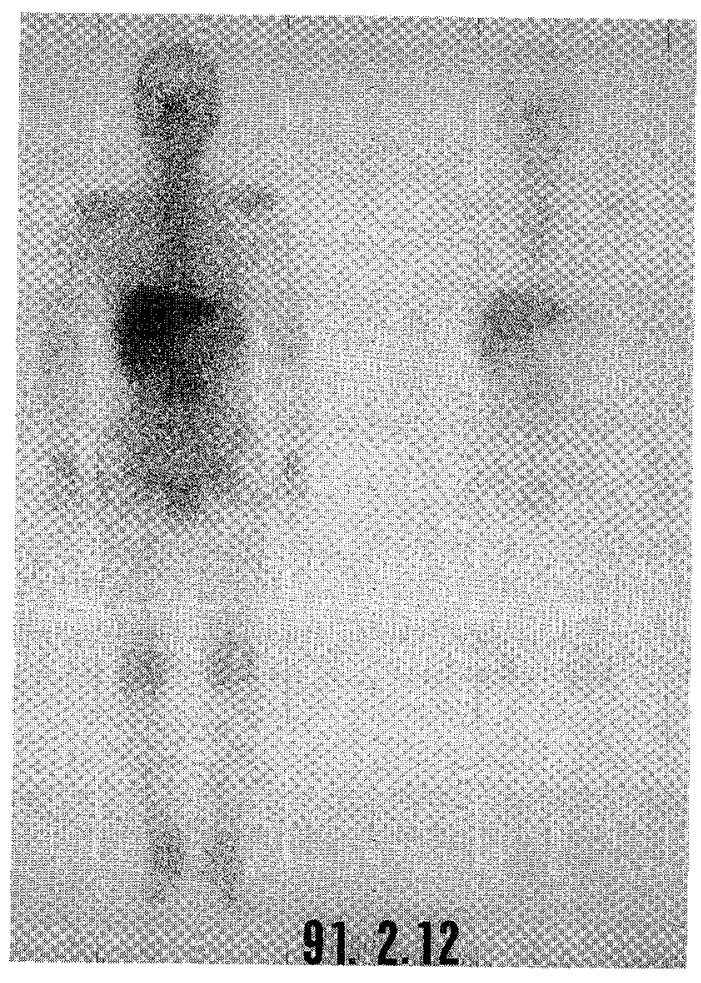

Fig. 1. ${ }^{67} \mathrm{Ga}$ scintigraphy shows a abnormal accumulation in the abdomen.

and tumor biopsy would be extremely difficult and risky because the tumor involved several arteries and veins. Fortunately, as the findings of abdominal CT and ultrasound echogram revealed that the tumor on his back side did not involve any major vessels and appeared to be easy to reach from his back, percutaneous lymph node biopsy from the back was performed under ultrasound echographic guide. The biopsy was done quite safely and the specimen obtained was $2 \mathrm{~cm}$ long and 


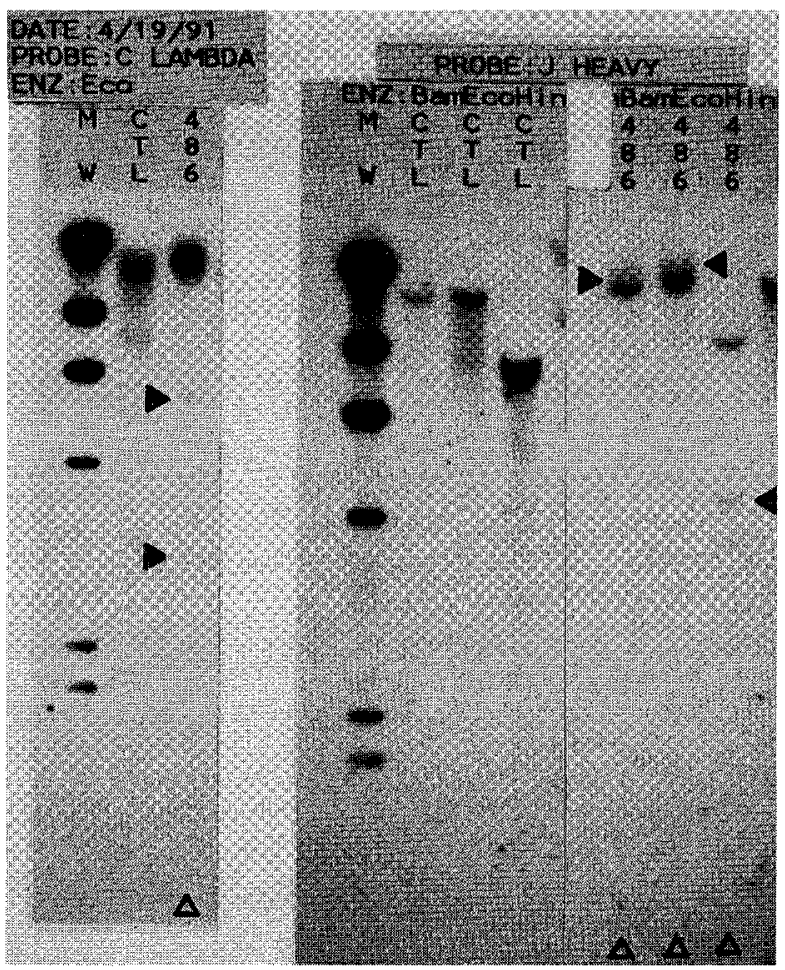

Fig. 5. Rearrangement patterns of immunoglobulin heavy chain and light chain genes on Hind III, BamH1, and EcoRI digests of the biopsy specimen (No. $486=$ present case). Monoclonal rearrangements of $\lambda$ chain (left side) and heavy chain (right side) are seen. CTL: control, MW: standard molecular weight.

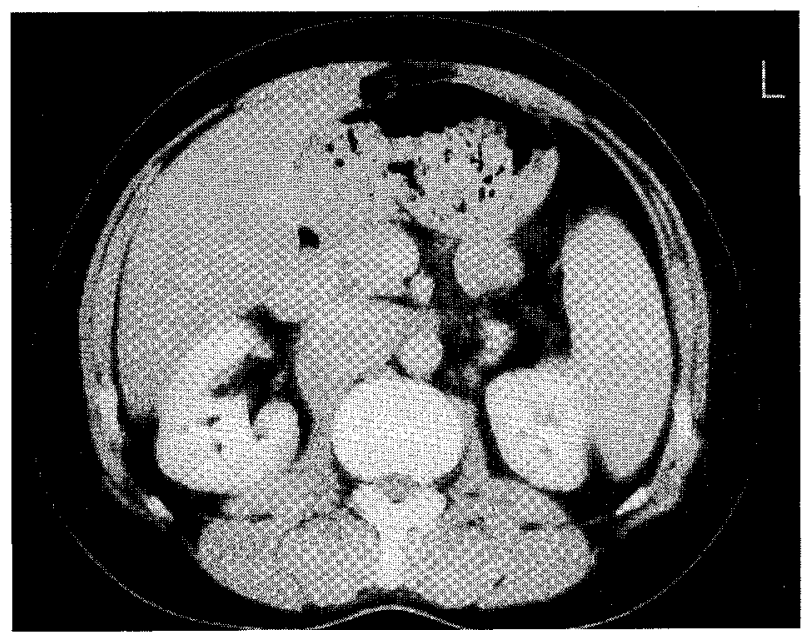

Fig. 6. Abdominal CT scan after 3 months of therapy with PSL reveals marked reduction of tumor size.

p.o., for 5 days) therapy was added, and the tumor disappeared. He has been followed up at our out-patient clinic, without any evidence of relapse for 18 months.

\section{Discussion}

One of the most important aspects for the differential diagnosis of malignant lymphoma from reactive lymphoproliferative disease would be the determination of the origin of the proliferating lymphoid cells and the monoclonality of those cells. In addition to the conventional morphological examination, monoclonal antibodies that can define cell surface antigens have been widely used in flowcytometrical and immunohistochemical analyses for this purpose (7). Although MoAbs are highly specific, sometimes it is difficult to detect the monoclonality of the lymphoid cells proliferated, probably due to the low percentage of monoclonal malignant cells. In contrast, it has been demonstrated recently that monoclonal rearrangement of Ig or TCR gene can be detected by the Southern blot hybridization technique from the specimen, even the percentage of monoclonaly proliferating cells is $1-5 \%$ (8). Furthermore, it has also been reported that the sensitivity can be greatly improved with the polymerase chain reaction (PCR) technique. In the present case, conventional Southern blot hybridization method was sufficient to detect monoclonal Ig gene rearrangement, indicating that monoclonally proliferating cells may be few and most of the cells proliferating in the lesion might be polyclonally activated lymphoid cells. The specimen obtained by needle biopsy was very tiny, but yet the DNA analysis was possible and useful for the diagnosis. This observation may be correlated with the findings that there was no significant increment of specific lymphoid cell subsets in the immunohistochemical study. The relationship between monoclonally proliferating cells and other polyclonally proliferating cells was not clear up to now. Recently, it has also been demonstrated that monoclonal Ig and TCR gene rearrangement are detected in some lymphoproliferative disorders, such as angioimmunoblastic lymphadenopathy (AILD) (9-10), and T cell lymphomatosis and cytopenia (11), other than malignant lymphoma. Although these diseases have been considered to be different disease entities, the detection of monoclonal Ig or TCR gene rearrangement in these diseases may suggest the existence of potentially monoclonal malignant cells. In general, Ig or TCR gene rearrangement was not detected in lymphoproliferative disorders associated with the inflamatory process, such as Hashimoto's thyroiditis (12). Recently, some reports have demonstrated that Ig or TCR gene rearrangement is detected in certain diseases that had been previously thought to be inflamatory disorders, indicating that these diseases might have both biologic and histologic features consistent with $T$ cell neoplasm despite their indolent course (13-15). From these reports, it would be worthwhile to examine the $\mathrm{Ig}$ and TCR gene rearrangement in the specimen along with the conventional histological examination, especially in cases when in whom enough 


\section{Ig Gene Rearrangement in Localized Lymphoma}

specimen can not be obtained or conventional laparotomic tumor biopsy can not be performed, such as present case. There would be no argument that laparotomic tumor biopsy should be done for better diagnosis, but it would have been difficult and risky in the present case. As percutaneous biopsy was safely performed and DNA analysis was very helpful in the diagnosis of this case, our approach would be of benefit not only for difinitive diagnosis, but also for the prevention of several complications associated with open surgery. Up to now, there has been no definitive report that clearly describes the relationship between the clinical prognosis and the existence of specific Ig or TCR gene rearrangements. In the present case, treatment with prednisolone alone was partially effective at first, but cytocidal anti-cancer drugs were required for the complete eradication of the tumor, indicating the existence of malignant clone in the tumor mass. Since the use of anti-cancer drug must be carefully administered because of second malignancies, the detection of the monoclonal Ig gene rearrangement was helpful for the determination of the treatment protocol. Taken together, the results described here demonstrated the diagnostic efficacy of percutaneous tumor biopsy and DNA analysis utilizing the Southern blot hybridization technique for ambiguous lymphoproliferative disorders.

Acknowledgment: The Southern blot hybridization assay of the present case was performed at Biomedical Laboratories, Kawagoe City, Saitama, Japan.

\section{References}

1) Berzofsky JA, Berkower IJ, Hasemann CA, et al. Antigens, antibodies, and receptors. in: Fundamental Immunology, Paul WE, Ed. Raven Press, New York, 1989, p. 169.

2) Tonegawa S. Somatic generation of antibody gene dynamics.
Nature 302: 575, 1983.

3) Yanagi Y, Yoshikai Y, Leggett K, Clark SP, Alexander I, Mak TW. A human $T$ cell-specific cDNA clone encodes a protein having extensive homology to immunoglobulin chains. Nature 308: 145, 1984.

4) Manser T, Wysocki LJ, Gridley T, Near RI, Gefter ML. The molecular evolution of the immune response. Immunol Today 6 : 94, 1985.

5) Cleary ML, Chao J, Warnke R, Sklar J. Immunoglobulin gene rearrangement as a diagnostic criterion of $\mathrm{B}$-cell lymphoma. Proc Natl Acad Sci USA 81: 593, 1984.

6) Southern EM. Detection of specific sequences among DNA fragments separated by gel electrophoresis. J Mol Biol 98: 503, 1975.

7) Knapp W, Reiber P, Dorken B, et al. Towards a better definition of human leukocyte surface molecules. Immunol Today 10: 253 , 1989.

8) Waldmann TA, Korsmeyer SJ, Bakkski A, et al. Molecular genetic analysis of human lymphoid neoplasms. Ann Intern Med 102: $497,1985$.

9) Daus H, Schwartze G, Pees H, Radtke H, Kumel G, Scheurlen PG. Immunoglobulin and T cell receptor gene rearrangements in lymphoproliferative disorders. Exp. Cell Biol 57: 177, 1989.

10) Tobinai T, Mukai K, Shimoyama M. AILD/IBL. Jpn J Clin Immunol 12: 506, 1989.

11) Berliner $N$, Duby $A D$, Linch $D C$, et al. $T$ cell receptor gene rearrangements define a monoclonal $\mathrm{T}$ cell proliferation in patients with T cell lymphomatosis and cytopenia. Blood 67: 914, 1986.

12) Ben-Ezra J, Wu A, Sheibani K. Hashimoto's thyroiditis lacks detectable clonal immunoglobulin and $\mathrm{T}$ cell receptor gene rearrangements. Human Pathology 19: 1444, 1988.

13) Weiss LM, Wood GS, Trela M, Warnke RA, Sklar J. Clonal $\mathrm{T}$ cell populations in lymphomatoid papulosis: Evidence of a lymphoproliferative origin for a clinically benign disease. N Engl Med 315: 475, 1986.

14) Weiss LM, Wood GS, Ellisen LW, Reynolds TC, Sklar J, Clonal $\mathrm{T}$ cell populations in Pityriasis Lichenoides et Varioliformis acuta (Mucha-Herbermann disease). Am J Pathol 16: 47, 1987.

15) Michiels JJ, van Dongen JJM, Hagemeijer A, et al. Richer's syndrome with identical immunoglobulin gene rearrangements in the chronic lymphocytic leukemia and the supervening nonHodgkin's lymphoma. Leukemia 3: 819, 1989. 